\title{
IMPLEMENTASI EVALUASI MODEL KUALITAS PROSES DAN OUTPUT PEMBELAJARAN PADA MATA KULIAH MAGANG I
}

\author{
St. Jumaeda ${ }^{1}$ \\ ${ }^{1}$ Prodi PAI FITK IAIN Ambon \\ jumaeda@iainambon.ac.id
}

\begin{abstract}
This research aims to obtain an overview of the implementation of evaluation of process quality models and output quality in Internship learning.l. This research is an evaluative research approach using a model developed by Widoyoko, Which includes two main components, namely: process quality and quality of learning output. The sample in this study was a student of the Islamic Religious Education study program of the Faculty of Tarbiyah Science and lain Ambon Teacher Training numbering 32 students. Data collection is obtained through document studies, interviews, questionnaires and observations. The data is then classified into very less, less, sufficient, good and excellent categories, based on the standards of assessment evaluation made at each stage of evaluation, and decision making. The findings in the evaluation of the Internship I Learning Program of Islamic Religious Education Faculty of Tarbiyah Science and IAIN Ambon Teacher Training, showed that the quality of the learning program process, including the good category, and the quality of internship learning output I also belonged to the excellent category. Taking into account the previous facts there are several aspects in the evaluation of the quality of the process and the quality of learning output that need to be improved so that internship learning I will be more effective and achieve the competencies that have been planned.
\end{abstract}

Keywords: evaluation of process quality and quality of learning output, internship I

\begin{abstract}
Abstrak: Penelitian ini bertujuan untuk memperoleh gambaran tentang implementasi evaluasi model kualitas proses dan kualitas output pada pembelajaran Magang I. Penelitian ini merupakan pendekatan penelitian evaluatif dengan menggunakan model yang dikembangkan oleh Widoyoko, yang mencakup dua komponen utama, yaitu: kualitas proses dan kualitas output pembelajaran. Sampel dalam penelitian ini adalah mahasiswa program studi Pendidikan Agama Islam Fakultas IImu Tarbiyah dan Keguruan IAIN Ambon berjumlah 32 mahasiswa. Pengumpulan data diperoleh melalui studi dokumen, wawancara, kuesioner dan observasi. Data kemudian diklasifikasikan ke dalam kategori sangat kurang, kurang, cukup, baik dan sangat baik, berdasarkan standar evaluasi penilaian yang dibuat pada setiap tahap evaluasi, dan pengambilan keputusan. Temuan dalam evaluasi program pembelajaran Magang I Prodi Pendidikan Agama Islam Fakultas IImu Tarbiyah dan Keguruan IAIN Ambon, menunjukkan bahwa kualitas dari proses program pembelajaran, termasuk kategori baik, dan kualitas output pembelajaran magang I juga termasuk dalam kategori sangat baik. Dengan mempertimbangkan fakta-fakta sebelumnya terdapat beberapa aspek dalam evaluasi kualitas proses dan kualitas output pembelajaran yang perlu ditingkatkan sehingga pembelajaran magang I akan lebih efektif dan mencapai kompetensi yang telah direncanakan.
\end{abstract}

Kata Kunci: evaluasi kualitas proses dan kualitas output pembelajaran, magang I

\section{PENDAHULUAN}

"Salah satu faktor utama pendukung keberhasilan pembangunan di suatu Negara adalah tersedianya Sumber Daya Manusia (SDM) yang berkualitas. Peningkatan kemampuan dan kualitas sumber daya manusia merupakan tantangan utama yang sedang dihadapi bangsa Indonesia saat ini. Berbagai upaya dalam peningkatan kualitas sumber daya manusia di Indonesia telah dilakukan oleh 
pemerintah diantaranya dengan melalui pelaksanaan pendidikan, namun praktek pendidikan di Indonesia selama ini kurang mampu menghasilkan sumber daya manusia yang memiliki keunggulan kompetitif. Menyadari rendahnya mutu dan kualitas pendidikan merupakan salah satu penyebab lemahnya kualitas sumber daya manusia dalam mendukung pembangunan nasional, maka pemerintah melakukan berbagai upaya dalam usaha peningkatan kualitas sumber daya manusia. Upaya tersebut diantaranya melalui lembaga pendidikan, yang sekaligus disertai dengan peningkatkan mutu dan kualitas pendidikan itu sendiri”.(Hajar, 2011)

"Esensi pendidikan yang berkualitas khususnya dalam penelitian ini diasumsikan sebagai proses pendidikan yang berkualitas sehingga dapat menghasilkan output atau menghasilkan lulusan yang sesuai dengan harapan dan kebutuhan masyarakat, baik dalam kualitas moral, pengetahuan, maupun kompetensi kerja. Peningkatan kualitas pendidikan dapat ditempuh melalui peningkatan kualitas pembelajaran dan kualitas sistem penilaian. Keduanya saling terkait, sistem pembelajaran yang baik akan menghasilkan kualitas belajar yang baik".(Trisnani et al., 2015)

"Untuk menghasilkan ouput yang berkualitas dibutuhkan evaluasi sebagai salah satu komponen yang tak kalah penting dengan proses pembelajaran. Ketika proses pembelajaran dipandang sebagai proses perubahan tingkah laku siswa, peran evaluasi proses pembelajaran menjadi sangat penting. Evaluasi merupakan suatu proses untuk mengumpulkan, menganalisa dan menginterpretasi informasi untuk mengetahui tingkat pencapaian tujuan pembelajaran oleh peseta didik. Sistem evaluasi yang baik akan mampu memberikan gambaran tentang kualitas pembelajaran sehingga pada gilirannya akan mampu membantu pengajar merencanakan strategi pembelajaran. Bagi peserta didik sistem evaluasi yang baik akan mampu memberikan motivasi untuk selalu meningkatkan kemampuannya".(Magdalena et al., 2020)

"Berdasarkan pada kurikulum perguruan tinggi berbasis KKNI dinyatakan bahwa program PPL dirubah menjadi program magang terdiri atas magang I, II dan III sebagai bagian integral dari mata kuliah profesi kependidikan, profesi keguruan dan Micro teaching. Pada kegiatan magang I ini kelompok mahasiswa bertugas melakukan observasi kultur sekolah, observasi dalam membangun ke empat kompetensi dasar guru dan melakukan observasi dalam rangka memperkuat 
pemahaman kompetensi dasar guru serta mendeskripsikan tugas tenaga pendidik dan tenaga kependidikan"(Ghoer, 2020).

"Magang Kependidikan sangat penting untuk memberikan bekal kepada mahasiswa tentang mengajar yang sesungguhnya, kegiatan ini terdiri dari tiga tahap: Magang Kependidikan I, II, dan III. Masing-masing kegiatan tersebut dilaksanakan sesuai dengan kebijakan program studi/ fakultas. Kegiatan magang tersebut diawali dengan orientasi mahasiswa ke sekolah mitra (pelaksanaan observasi sekolah/kelas) kemudian pada tahap akhir, mahasiswa magang melaksanakan praktik mengajar di sekolah. Kegiatan magang ini memberikan pengalaman awal untuk membangun jati diri pendidik, memantapkan kompetensi kependidikan dan bidang studi, memantapkan kemampuan awal mahasiswa calon guru, mengembangkan perangkat pembelajaran dan kecakapan pedagogis"(Octavianingrum, 2020).

"Program magang merupakan kegiatan pembelajaran yang dilakukan mahasiswa untuk mendapatkan pengalaman dalam berkontribusi dan berkarya di kehidupan nyata. Dengan demikian diharapkan setiap mahasiswa mampu mengikuti dan memahami kegiatan pembelajaran yang dilakukan di sekolah/madrasah sehingga mahasiswa tersebut memperoleh pengalaman sebagai bekal bagi dirinya serta mampu menunjukkan kinerjanya secara maksimal. Selain itu dapat membentuk mental motivasi mahasiswa sebagai sebagai calon guru yang profesional".(Effrisanti, 2015)

"Mahasiswa sebagai personal yang berada pada generasi emas perlu meningkatkan profesionalitas dan keterampilan sesuai dengan bidang keilmuannya. Salah satu upaya yang dapat dilakukan untuk meningkatkan profesionalitas dan keterampilan mahasiswa adalah program magang. Magang adalah sebuah program yang ditujukan kepada mahasiswa yang telah menyelasikan mata kuliah prasyarat magang. Progam magang memiliki banyak manfaat, antara lain mahasiswa mendapatkan kesempatan untuk mempraktikkan teori yang telah diperoleh di dalam kelas, memiliki pengalaman untuk bekerjasama dengan pihak luar terkait bidang kelimuannya, dan segala hal yang berakitan dengan profesionalitasnya. Tanpa adanya program magang, maka mahasiswa tidak akan mempunyai persiapan yang matang terkait rencana yang akan dilaksanakan nanti ketika sudah terjun di dalam dunia kerjanya seuai dengan apa yang dipelajari di dalam bangku kuliah".(Fahrudin \& Fauziah, 2021) 
"Program pembelajaran magang yang dilakukan mahasiswa di sekolah/madrasah adalah program pembelajaran yang bertujuan untuk mengembangkan komptensi mahasiswa dalam melaksanakan proses pembelajaran di kelas. Penyelnggaraan program pembelajaran tersebut tentunya bertujuan agar segala kompetensi, indikator dan tujuan-tujuan pembelajaran dapat tercapai. Keberhasilan program pembelajaran sangat tergantung pada sejauh mana kompetensi, indikator dan tujuan-tujuan pembelajaran tersebut dapat tercapai dengan baik. Informasi tersebut dapat diperoleh dengan melakukan evaluasi pembelajaran dengan instrumen dan prosedur-prosedur yang tepat”(Herwin, 2019)

"Model EKOP merupakan salah satu bentuk evaluasi yang menggunakan pendekatan penilaian proses dan hasil. Penilaian proses dalam hal ini disebut dengan penilaian kualitas hasil pembelajaran, sedangkan penilaian kualitas hasil pembelajaran disebut penilaian output pembelajaran, sehingga nama model ini disebut dengan model evaluasi kualitas proses dan output pembelajaran (Model EKOP). Evaluasi model EKOP disusun berdasarkan kerangka pikir bahwa untuk mengevaluasi keberhasilan program pembelajaran, tidak hanya dengan menilai output belajar siswa semata, namun perlu menilai proses implementasi program dalam kelas, yang dalm penelitian ini disebut dengan kualitas pembelajaran".(Raupu, 2018)

"Peningkatan kualitas proses dan kualitas output pembelajaran magang I sangat ditentukan oleh tiga unsur, yaitu: dosen, mahasiswa, dan kurikulum. Ketiga unsur tersebut dapat diasumsikan bahwa (1) dosen, sesuai dengan fungsinya bertugas mengoptimalkan kemampuan mahasiswa dalam pembelajaran. Dalam mengoptimalkan kemampuan mahasiswa profesionalisme, kemampuan dan pemahaman dosen yang memadai dalam mengajar sangat menentukan peningkatan kualitas pembelajaran sekaligus keberhasilan program pembelajaran mencapai tujuan sebagaimana telah direncanakan di dalam Rencana Pembelajaran Semester (RPS) yang telah disusun sebelumnya, (2) mahasiswa, dengan segala karakteristiknya dalam proses pembelajaran diharapkan secara maksimal dapat mencapai tujuan belajar. Karakteristik mahasiswa yang dimaksud khususnya dalam penelitian ini diantaranya menyangkut derajat afeksi atau sikap siswa, motivasi, personal skill, dan social skill yang dapat dioptimalkan untuk meningkatkan kualitas maupun output pembelajaran, dan (3) Kurikulum merupakan pedoman atau media serta sekaligus merupakan salah satu fasilitas penunjang untuk mencapai tujuan 
yang diinginkan. Oleh karena itu, maka perlu dilakukan evaluasi pada unsur-unsur tersebut untuk mengidentifikasi kualitas proses dan kualitas output"(Jumaeda, 2018).

Kualitas proses dan kualitas output pembelajaran pada mata kuliah magang I pada program studi Pendidikan Agama Islam Fakultas IImu Tarbiyah dan Keguruan IAIN Ambon melalui tiga komponen penting program pembelajaran yang saling terkait, yaitu perencanaan pembelajaran, pelaksanaan proses pembelajaran, dan penilaian. Perencanaan pembelajaran merupakan persiapan mengelola pembelajaran yang akan dilaksanakan pada setiap tatap muka. Pelaksanaan proses pembelajaran merupakan kegiatan dosen dalam mengelolah pembelajaran di kelas. Kegiatan penilaian dilakukan untuk mengukur dan menilai pencapaian kompetensi serta untuk mengetahui kelebihan dan kekurangan dari proses pembelajaran yang telah dilaksanakan. Program pembelajaran perlu dirancang secara terencana agar pelaksanaan pembelajaran berjalan dengan baik. Karena saling terkait inilah, maka perencanaan pembelajaran yang baik sangat penting untuk menjamin terlaksananya proses pembelajaran yang efektif dan benar.

Berdasarkan hasil survey menunjukkan bahwa mayoritas dosen, termasuk termasuk dosen magang I telah memiliki perencanaan pembelajaran, namun apakah dosen mata kuliah tersebut melaksanakan perencanaan pembelajaran sesuai dengan capaian pembelajaran mata kuliah yang telah ditetapkan oleh program studi, sebab perencanaan proses akan terkait erat dengan pelaksanaan penilaian yang sangat berpengaruh terhadap peningkatan kualitas proses dan kualitas output pembelajaran yang pada akhirnya berujung pada peningkatan mutu pendidikan itu sendiri. Sehingga dengan demikian perlu dievaluasi untuk mengidentifikasi bagaimana kualitas proses dan kualitas output pembelajaran magang I pada program studi Pendidikan Agama Islam Fakultas IImu Tarbiyah IAIN Ambon.

\section{METODE}

Penelitian ini merupakan penelitian evaluasi dengan menggunakan model kualitas proses dan kualitas output pembelajaran, yang mencakup berbagai aspek indikator yang terkait dengan kualitas proses dan kualitas output program pembelajaran mata kuliah magang I yang dievaluasi. Penelitian ini dilaksanakan di program studi pendidikan agama Islam fakultas ilmu tarbiyah dan keguruan IAIN Ambon dengan jumlah sampel sebanyak 32 mahasiswa. Teknik pengumpulan data dilakukan melalui observasi, wawancara, angket, dan dokumentasi. Data mentah hasil evaluasi kualitas proses dan kualitas output pembelajaran melalui teknik 
observasi, wawancara, angket dan dokumentasi ditabulasi kemudian mengalami peruduksian. Selanjutnya data dari hasil tabulasi kemudian dipersentasekan dan dikategorikan untuk dideskripsikan. "Sumber data yang didapatkan pada setiap unit analisis juga dikonfirmasi dengan metode tri-angulasi untuk mengetahui data yang diperoleh convergent (meluas), tidak konsisten atau kontradiksi. Oleh karena itu dengan menggunakan teknik triangulasi dalam pengumpulan data, maka data yang diperoleh akan lebih konsisten, tuntas dan pasti”.(Sugiono, 2009)

\section{HASIL}

\section{A. Evaluasi Kualitas Proses Pembelajaran}

Penilaian pada evaluasi kualitas proses dilakukan untuk mengidentifikasi proses program pembelajaran magang I, mencakup penilaian terhadap kinerja dosen dalam pembelajaran, dan sikap mahasiswa dalam pembelajaran untuk mewujudkan tujuan program pembelajaran khususnya pada pembelajaran magang I yang diselenggarakan di Program studi Pendidikan Agama Islam Fakultas IImu Tarbiyah dan Keguruan IAIN Ambon.

\section{Kinerja Dosen}

Evaluasi terhadap komponen kinerja dosen dilaksanakan melalui evaluasi pada aspek-aspek, yaitu: Penguasaan materi, Pemahaman karakteristik mahasiswa, Penguasaan pengelolaan pembelajaran, kemampuan membimbing mahasiswa dan kemampuan melaksanakan penilaian.

Berdasarkan hasil penilaian mahasiswa Program Studi Pendidikan Agama Islam Fakultas IImu Tarbiyah dan Keguruan IAIN Ambon yang dijaring melalui kuesioner yang telah disebarakan kepada 32 mahasiswa, diperoleh gambaran Kualitas proses program pembelajaran magang I ditinjau dari aspek kinerja dosen sebagai berikut: 


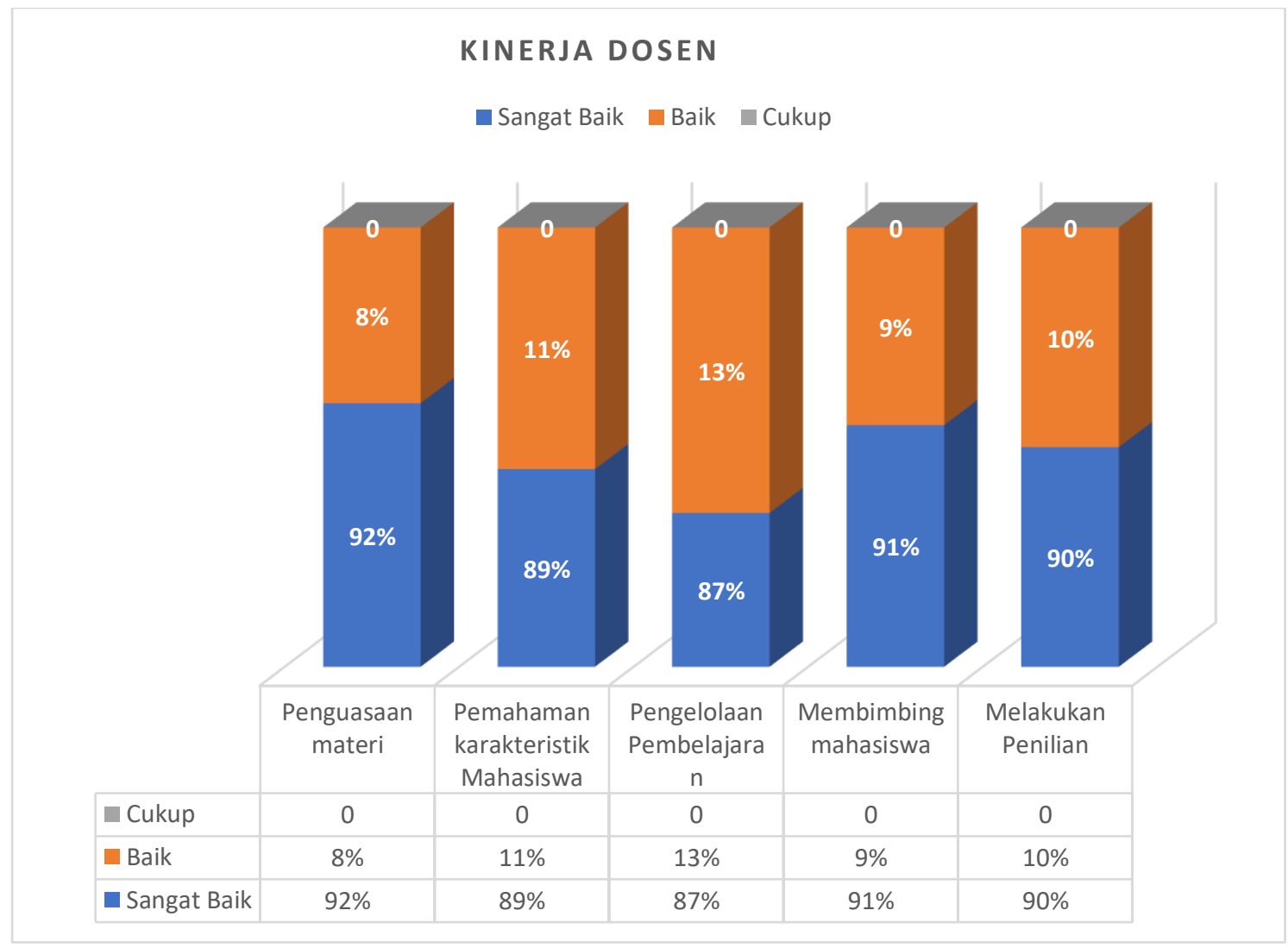

Berdasarkan data di atas menunjukkan bahwa dosen pada mata kuliah magang I memiliki kemampuan penguasaan materi dengan presentasi 92\% mahasiswa menyatakan sangat baik, dan 8\% menyatakan baik. Hal tersebut menunjukkan bahwa Penguasaan materi atau kompetensi yang dimiliki oleh dosen magang I termasuk pada kategori sangat baik. Untuk pemahaman karakteristik mahasiswa, diberdasarkan dari jawaban 32 mahasiswa dengan presentase sebesar $89 \%$ menyatakan sangat baik dan $11 \%$ menyatakan baik. Hal demikian menunjukkan bahwa deskripsi terhadap kemampuan dosen dalam Pemahaman karakteristik siswa dinilai sangat baik.

Sementara penguasaan pengelolaan pembelajaran berdasarkan dari jawaban 32 mahasiswa memperoleh skor sebesar $87 \%$ menjawab sangat baik dan 13\% menjawab baik. Hal demikian menunjukkan bahwa kompetensi atau kemampuan dosen terhadap Penguasaan pengelolaan pembelajaran dinilai sangat baik. Sementara kemampuan membimbing mahasiswa didasarkan dari jawaban 32 mahasiswa memperoleh skor sebesar 91\% menyatakan sangat baik dan 9\% menyatakan baik. Hal demikian menandakan bahwa kompetensi atau kemampuan dosen dalam membimbing mahasiswa dalam mata kuliah magang I berada dalam kategori sangat baik. Pada Kemampuan melaksanakan penilaian melalui jawaban 
32 mahasiswa menyatakan bahwa $90 \%$ sangat baik dan $10 \%$ menyatakan baik . Hal demikian menunjukkan bahwa kemampuan melaksanakan penilaian yang dimiliki oleh dosen berada pada kategori baik.

Secara keseluruhan, hasil penilaian dari evaluasi, berdasarkan penilaian mahasiswa prodi Pendidikan agama Islam fakultas IImu tarbiyah dan keguruan IAIN menunjukkan bahwa secara umum kompetensi yang dimiliki dosen ditinjau dari aspek kinerja dosen dalam menyelenggarakan program pembelajaran magang I di program studi Pendidikan agama Islam Fakultas IImu Tarbiyah dan Keguruan IAIN Ambon dinilai sangat baik.

Berdasarkan dari hasil evaluasi yang dilakukan melalui observasi terhadap kemampuan dosen dalam melaksanakan penilaian, diketahui bahwa teknik penilaian yang dilakukan guru telah sesuai dengan capaian pembelajaran mata kuliah, kejelasan prosedur penilaian, kelengkapan alat penilaian dan penilaian dilakukan selama proses pembelajaran.

\section{Sikap Mahasiswa dalam Pembelajaran}

Sikap mahasiswa terhadap kecenderungan dalam mengikuti pelaksanaan program pembelajaran magang I pada program studi Pendidikan Agama Islam Fakultas IImu Tarbiyah dan Keguruan IAIN Ambon berdasarkan hasil penilaian mahasiswa, seperti disajikan sebagai berikut:

\section{Sikap Mahasiswa}

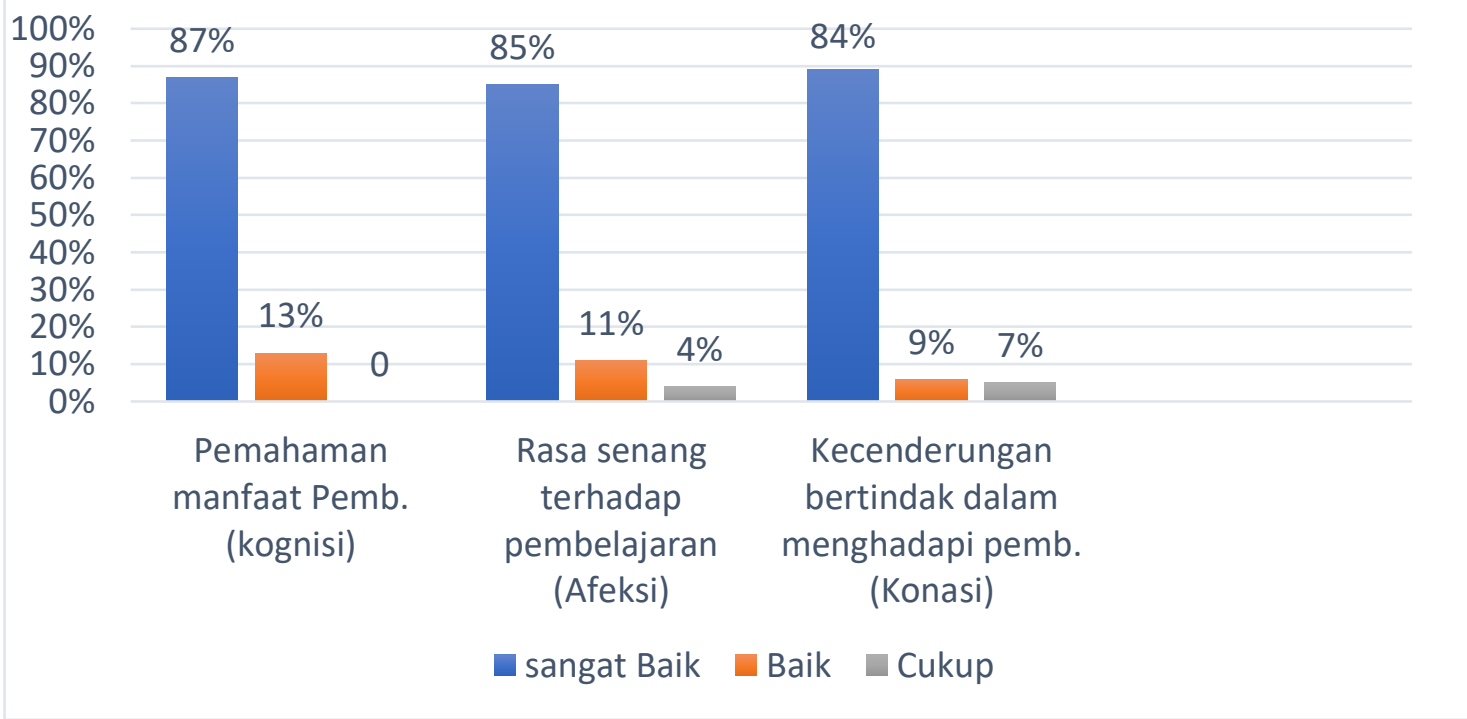


Sikap mahasiswa terhadap manfaat pembelajaran (kognisi) berdasarkan dari jawaban mahasiswa menunjukkan bahwa 87\% mahasiswa menyatakan sangat baik dan $13 \%$ menyatakan baik serta tidak ada yang menyatakan cukup. Hal tersebut mengindikasikan bahwa pemahaman materi yang dimiliki mahasiswa khususnya mata kuliah magang I pada program studi Pendidikan Agama I Fakultas IImu Tarbiyah dan Keguruan IAIN Ambon dinilai sangat baik.

Pada butir rasa senang terhadap mata kuliah magang I menurut penilaian mahasiswa menunjukkan bahwa $85 \%$ menyatakan sangat baik, $11 \%$ i menyatakan baik, dan 4\% menyatakan cukup. Hal demikian menunjukkan bahwa perasaan siswa terhadap pelaksanaan program pembelajaran magang I pada Program Studi Pendidikan Agama Islam Fakultas IImu Tarbiyah dan Keguruan IAIN Ambon dinilai baik.

Pada butir aspek kecenderungan bertindak berdasarkan penilaian mahasiswa menunjukkan bahwa 84\% mahasiswa menyatakan sangat baik, 9\% menyatakan baik dan 7\% menyatakan cukup. Hal demikian menunjukkan bahwa kecenderungan mahasiswa terhadap mata mata kuliah, materi maupun dosen dinilai baik.

Secara keseluruhan berdasarkan hasil evaluasi tentang sikap mahasiswa dari menunjukkan bahwa sikap mahasiswa terhadap materi pelajaran maupun dosen dalam menyelenggarakan program pembelajaran Magang I pada Program Studi Pendidikan Agama Islam Fakultas IImu Tarbiyah dan Keguruan IAIN Ambon dinilai baik.

Berdasarkan evaluasi pada penelitian dengan tujuan untuk mengidentifikasi kualitas proses dari pelaksanaan program pembelajaran magang I, pada Program Studi Pendidikan Agama Islam Fakultas IImu Tarbiyah dan Keguruan IAIN Ambon setelah melalui penilaian yang dilakukan oleh 32 orang mahasiswa selaku responden menunjukan bahwa kualitas proses pembelajaran magang I yang diselenggarakan di Program Studi Pendidikan Agama Islam Fakultas IImu Tarbiyah dan Keguruan IAIN Amboni menurut mahasiswa dinilai sangat baik.

\section{B. Evaluasi Kualitas Output Pembelajaran}

Penilaian pada evaluasi kualitas output dilakukan untuk mengidentifikasi hasil program pembelajaran yaitu penilaian terhadap kecakapan akademik mahasiswa dengan tujuan untuk mengidentifikasi dan mengetahui hasil dari pelaksanaan program pembelajaran pada mata kuliah magang I yang 
diselenggarakan di program studi pendidikan agama Islam Fakultas IImu Tarbiyah dan Keguruan IAIN Ambon.

Analisis terhadap kecakapan akademik mahasiswa dilakukan terhadap data mengenai hasil belajar mahasiswa pada mata kuliah magang I. Gambaran mengenai kecakapan akademik mahasiswa sebagai hasil dari pelaksanaan program pembelajaran magang I pada program sutdi Pendidikan Agama Islam Fakultas IImu Tarbiyah dan Keguruan IAIN Ambon terlihat pada hasil Ujian Akhir Semester ganjil (lima) tahun akademik 2021/2022 sebagai berikut:

\begin{tabular}{ccccc}
\hline No & Skala & $\begin{array}{c}\text { Nilai } \\
\text { Huruf }\end{array}$ & $\begin{array}{c}\text { Angka } \\
\text { konversi }\end{array}$ & $\begin{array}{c}\text { Jumlah } \\
\text { Mahasiswa }\end{array}$ \\
\hline $\mathbf{1}$ & $91-100$ & A & 4.00 & 7 \\
\hline $\mathbf{2}$ & $81-90$ & B+ & 3.50 & 16 \\
\hline $\mathbf{3}$ & $71-80$ & B & 3.00 & 6 \\
\hline $\mathbf{4}$ & $61-70$ & C & 2.50 & 3 \\
\hline $\mathbf{5}$ & $50-60$ & D & 2.00 & 0 \\
\hline $\mathbf{6}$ & $00-49$ & E & 0.00 & 0 \\
\hline & & Total & & 32
\end{tabular}

Berdasarkan tabel di atas menunjukkan bahwa dari 32 mahasiswa mengikuti kuliah magang I, 7 mahasiswa (21,87\% memperoleh nilai A, 16 mahasiswa $(50 \%)$ memperoleh nilai $\mathrm{B}+, 6$ mahasiswa (18,75\%) memperoleh nilai $\mathrm{B}, 3$ mahasiswa (9.37\%) memperoleh nilai $C$ dan tidak ada mahasiswa memperoleh nilai $D$ dan $E$. Hal tersebut menujukkan bahwa nilai hasil belajar yang dicapai mahasiswa cukup tinggi atau dapat dikatakan bahwa kecakapan akademik yang dicapai mahasiswa dalam program pembelajaran magang I di Program studi Pendidikan Agama Islam Fakultas IImu Tarbiyah Dan Keguruan IAIN Ambon termasuk pada kategori sangat baik.

\section{PEMBAHASAN}

Dalam pelaksanaan program pembelajaran magang I di Program studi Pendidikan Agama Islam Fakultas IImu Tarbiyah dan Keguruan IAIN Ambon, berdasarkan hasil evaluasi pada aspek kinerja dosen menunjukkan kategori sangat baik, yang berarti rumusan kemampuan dosen dalam menunjukkan keterampilan atau kompetensi yang dimiliki dosen pada waktu mengajar di kelas dinilai dengan 
kategori sangat baik. Hal tersebut ditentukan oleh aspek-aspek diantaranya penguasaan materi, pemahaman karakteristik siswa, penguasaan pengelolaan pembelajaran, kemampuan membimbing mahasiswa dan kemampuan melaksanakan penilaian. Terkait dengan penguasaan materi dalam pelaksanaan pembelajaran dosen memiliki kemampuan untuk mengaitkan materi dengan permasalahan yang relevan dengan pembelajaran di sekolah/madrasah, dengan mencontohkan kejadian-kejadian atau proses pelaksanaan pembelajaran di sekolah/ madrasah.

Pada aspek pemahaman karakteristik mahasiswa nampak pada dukungan dosen terhadap mahasiswa yang memiliki pemahaman yang kurang, pembelajaran dilakukan melalui pembelajaran individual. Pada aspek penguasaan pengelolaan pembelajaran dosen dalam pemilihan dan pengorganisasian bahan pembelajaran, dilakukan dengan mengacu pada kemampuan dan karakteristik mahasiswa. pada aspek kemampuan membimbing, untuk meningkatkan sikap kedisiplinan mahasiswa dalam mengikuti pembelajaran, maka dikembangkan menejemen dalam pengololaan sekolah/madrasah dengan selalu menekankan pada disiplin dalam segala aktifitas pelaksanaan kegiatan pembelajaran. Dalam kegiatan pembimbingan dosen dapat membangun hubungan yang akrab dengan mahasiswa, melalui pemberian ruang yang cukup pada mahasiswa untuk mengembangkan kreasi dan ide-idenya, selanjutnya dosen selalu memberikan dukungan jika ada kegiatan yang akan dilaksanakan oleh mahasiswa, sepanjang kegiatan tersebut berkaitan dengan kegiatan pembelajaran, dan hubungan yang baik antara dosen dan mahasiswa tersebut tidak terbatas pada pembelajaran di kelas saja akan tetapi juga di luar kelas

Pada aspek kemampuan melaksanakan penilaian, dosen melakukan penilaian dengan obyektif dan adil, jadi nilai yang diberikan adalah benar-benar sesuai dengan kemampun yang dimiliki mahasiswa, dengan tidak membedabedakan antara satu sama lainnya meskipun memiliki perbedaan Suku Agama Ras Golongan (SARG). Dengan demikian penilaian benar-benar dapat mengukur kompetensi mahasiswa sesuai dengan mata kuliah yang telah diajarkan. Pemberian tugas kepada mahasiswa dilakukan oleh dosen mata kuliah, melalui tugas tersebut dosen kemudian memberikan balikan (feedback) terhadap tugas-tugas yang dikerjakan mahasiswa, dengan membahas secara bersama-sama dengan mahasiswa misalnya dengan menanyakan kembali kepada mahasiswa terkait dengan tugas-tugas yang telah diselesaikan. Selanjutnya dilakukan penilaian 
terhadap hasil belajar melalui penilaian proses yang dilakukan pada saat pembelajaran sedang berlangsung, sedangkan penilaian formatif pada pertengahan sumester dan penilaian sumatif pada akhir semester.

Bertolak dari uraian di atas maka secara keseluruhan evaluasi pada komponen kualitas proses pembelajaran menunjukkan hasil yang sangat baik namun terdapat satu aspek dari komponen kualitas proses pembelajaran, yaitu aspek sikap mahasiswa melalui jawaban responden terhadap angket yang diberikan diketahui bahwa ternyata aspek yang perlu ditingkatkan, adalah: aspek kecenderungan bertindak menurut responden perlu diperbaiki, karena itu perlu dilakukan dengani cara dosen menganjurkan pada mahasiswa untuk selalu perhatian dalam mengikuti program pembelajaran dan aspek orientasi keberhasilan dalam pembelajaran magang I menurut responden perlu ditingkatkan, karena itu perlu dilakukan dengan cara menganjurkan pada mahasiswa untuk mencari solusi jika mengalami kendala belajar dalam usaha mencapai prestasi.

Untuk evaluasi komponen kualitas output pembelajaran dilakukan melalui penilaian terhadap kecakapan akademik mahasiswa dalam pelaksanaan program pembelajaran magang I di Program Studi Pendidikan Agama Islam Fakultas IImu Tarbiyah Dan Keguruan IAIN Ambon, berdasarkan hasil evaluasi pada aspek tersebut diperoleh 7 mahasiswa (21,87\% memperoleh nilai A, 16 mahasiswa $(50 \%)$ memperoleh nilai $\mathrm{B}+, 6$ mahasiswa (18,75\%) memperoleh nilai $\mathrm{B}, 3$ mahasiswa (9.37\%) memperoleh nilai $\mathrm{C}$ dan tidak ada mahasiswa memperoleh nilai $\mathrm{D}$ dan $\mathrm{E}$. yang berarti kecakapan akademik siswa menunjukkan bahwa kompetensi dasar yang dapat dikuasai atau dimiliki siswa setelah mengiuti kegiatan pembelajaran dinilai temasuk pada kategori sangat baik.

\section{KESIMPULAN}

Hasil evaluasi pada komponen kualitas proses pembelajaran, dalam pembelajaran magang I pada program studi PAI fakultas IImu tarbiyah dan keguruan IAIN Ambon, menunjukkan bahwa penilaian kualitas proses pembelajaran, ditentukan oleh unsur (1) Kinerja dosen yang dinilai dengan kategori sangat baik meliputi kemampuan penguasaan materi 92\%, pemahaman karakteristik mahasiswa, 89\%, pengelolaan pembelajaran, 87\%, kemampuan membimbing mahasiswa $91 \%$ dan kemampuan melakukan penilaian 90\%. (2) Sikap siswa dinilai dengan kategori baik didasarkan pada hasil penialian dan kategorisasi meliputi aspek 
kognisi $87 \%$, afeksi $85 \%$ dan konasi $84 \%$. Hal ini menunjukkan bahwa kualitas proses pembelajaran magang I dinilai termasuk pada kategori sangat baik. Pada komponen output pembelajaran diperoleh $21,87 \%$ mahasiswa memperoleh nilai $A, 50 \%$ mahasiswa memperoleh nilai $\mathrm{B}_{+}, 18,75 \%$ mahasiswa memperoleh nilai $\mathrm{B}, 9.37 \%$ mahasiswa memperoleh nilai $\mathrm{C}$ dan tidak ada mahasiswa memperoleh nilai $D$ dan $E$, yang berarti bahwa kecakapan akademik mahasiswa setelah mengiuti kegiatan pembelajaran dinilai temasuk pada kategori baik.

\section{Daftar Pustaka}

[1] Effrisanti, Y. (2015). Pembelajaran Berbasis Proyek Melalui Program Magang Sebagai Upaya Peningkatan Soft Skills Mahasiswa. Jurnal Eksis, X(1), 28-41.

[2] Fahrudin, A., \& Fauziah, A. (2021). Persepsi Mahasiswa lain Tulungagung Terhadap Pelaksanaan Program Magang Di Mtsn 2 Kota Blitar. Ta'allum: Jurnal Pendidikan Islam, 8(2), 377-400. https://doi.org/10.21274/taalum.2020.8.2.377400

[3] Ghoer, H. F. (2020). Sekolah Mitra Sebagai Komunikator Pelaksanaan Magang Penguasaan Kompetensi Calon Pendidik Pada Fakultas Keguruan Dan IImu Pendidikan. Gunahumas, 2(1), 248-263. https://doi.org/10.17509/ghm.v2i1.23046

[4] Hajar. (2011). No TitleEvaluasi Implementasi Kurikulum Taingkat Satuan Pendidikan untuk Pembelajaran Pendidikan Kewarganegaraan Pada MAN 1 Kendari.

[5] Herwin. (2019). Evaluation of Social Studies Learning Program at Sekolah Dasar Negeri 126 Lagoe. 1. https://journal.uny.ac.id/index.php/didaktika

[6] Jumaeda, S. (2018). Evaluation Implementation of Curriculum Unit Level of Education for Arabic Lenguage Learning in Mts Ddi Seppange. Al-Iltizam: Jurnal Pendidikan Agama Islam, 3(2), 90. https://doi.org/10.33477/alt.v3i2.599

[7] Magdalena, I., Fauzi, H. N., Putri, R., \& Tangerang, U. M. (2020). Pentingnya Evaluasi Dalam Pembelajaran Dan Akibat Memanipulasinya. Pendidikan Dan Sains - Stitpn, $244-257$. https://ejournal.stitpn.ac.id/index.php/bintang/article/download/986/680/

[8] Octavianingrum, D. (2020). Pentingnya Kompetensi Pedagogik Dalam Kegiatan Magang Kependidikan Bagi Mahasiswa Calon Guru. Jurnal IImiah Kependidikan, Vol 7(No 2), 115-124 hlm. http://ejournal.uikabogor.ac.id./index.php/index 
[9] Raupu, S. (2018). Analisis Kualitas Pembelajaran Guru Matematika dengan Menggunakan Model EKOP di SMK Teknologi Tri Tunggal $\$ 45$ Makassar. AlKhwarizmi: Jurnal Pendidikan Matematika Dan IImu Pengetahuan Alam, 4(1), 89-102. https://doi.org/10.24256/jpmipa.v4i1.254

[10] Sugiono. (2009). Metode Penelitian Kuantitatif Kualitatif dan $R \& D$.

[11] Trisnani, I., Hasyim, A., \& Djasmi, S. (2015). Evaluasi Program Pembelajaran IPA Kelas VIII di SMP Negeri Terbuka 20 Bandar Lampung. Jurnal Teknologi

$$
\text { Komunikasi Pendidikan, }
$$$$
\text { 2(2), }
$$
$1-15$. https://media.neliti.com/media/publications/193296-ID-evaluasi-programpembelajaran-ipa.pdf 